\title{
Investment Incentives in the European Union and Selected World Countries ${ }^{1}$
}

Ersan ÖZ (https://orcid.org/0000-0002-1847-8841), Department of Public Finance, Pamukkale University, Turkey; e-mail: ersanoz@gmail.com

Selçuk BUYRUKOĞLU (https://orcid.org/0000-0003-4335-1575), Department of Public Finance, Niğde Ömer Halisdemir University, Turkey; e-mail: sbuyrukoglu@ohu.edu.tr

\section{Avrupa Birliği ve Seçilmiş Dünya Ülkelerinde Yatırım Teşvikleri²}

\begin{abstract}
In this study, investment incentive policies and investment promotion tools employed in the European Union and other selected world countries such as the USA, China, Japan, Russia and South Korea were examined. Firstly, place of the incentive policy recognized throughout the European Union within the Union's legislation is given. In addition, investment promotion tools of each EU member state have been tabulated in a collective manner. After explaining investment incentives employed in the European Union each country stated above were discussed upon one by one. Investment promotion policies and tools applied in these countries were given to underline importance given by those countries to investment.
\end{abstract}

Keywords $\quad$ : Investment Incentives, EU, Selected World Countries.

JEL Classification Codes : D92, O31.

\section{Öz}

Bu çalışmada, Avrupa Birliği ve seçilmiş dünya ülkeleri olan; ABD, Çin, Japonya, Rusya ve Güney Kore'de uygulanan yatırım teşvik politikalarına ve yatırım teşvik araçlarına yer verilmiştir. İlk olarak, Avrupa Birliğinde genel kabul görmüş teşvik politikasının birliğe ait mevzuattaki yeri ele alınmıştır. Ayrıca her bir AB üyesi ülkenin yatırım teşvik araçlarına da toplu bir tablo halinde yer verilmiştir. Avrupa Birliğinde yatırım teşviklerine ilişkin açıklamalardan sonra ise yukarıda sayılan ülkeler sırasıyla ele alınmıştır. Bu ülkelerde uygulanan yatırım teşvik politikaları ve araçları ele alınarak, ilgili ülkelerin yatırımlara vermiş oldukları öneme vurgu yapılmıştır.

Anahtar Sözcükler : Y Yatırım Teşvikleri, AB, Seçilmiş Dünya Ülkeleri.

1 This study is derived from the dissertation titled "Investment Incentive Policies and Their Macroeconomic Effects: An Emprical Analysis for Turkey” and prepared by Selçuk Buyrukoğlu at Pamukkale University, Institute of Social Sciences, Department of Public Finance.

2 Çalışma, Pamukkale Üniversitesi Sosyal Bilimler Enstitüsü Maliye Anabilim Dalında Selçuk Buyrukoğlu tarafindan hazırlanan "Yatırım Teşvik Politikaları ve Makroekonomi Etkileri: Türkiye İçin Amprik Analiz", başlıklı doktora tezinden türetilmiştir. 


\section{Introduction}

The European Union and many leading world countries develop various policies in order to provide national and international economic confidence. Especially investment incentives proposed to be effective in terms of many macroeconomic variables by attracting foreign investments to the country take a large share in this context. World countries, being aware of this fact, employ various investment promotion tools and try to obtain direct investments rather than speculative ones. Thus, speculative investments would flee from the country depending on economic fluctuations, giving way to direct investments; which means an important step taken towards sustainable economy and global competition. Each legal arrangement made has led to new ones depending on global competition and investment incentives had become more attractive to investors. Investment incentives mainly in the form of tax related arrangements include cost-minimizing tools for investors such as $R \& D$ supports, allocation of space for investment, interest support and support for insurance premium employer share.

\section{The European Union and Investment Incentives}

Establishment of the European Union goes back to the European Coal and Steel Community. In parallel to circumstances arisen after the World War II a cooperative understanding to act together had emerged among the European countries; which resulted in establishment of the European Coal and Steel Community (ECSC) with the Treaty of Paris of 18 April 1951 made among six European countries: Germany, France, Italy, Belgium, the Nederland and Luxemburg (Bilici, 2007: 38).

Several arrangements had been developed to ensure cooperation among such member states; one of which arrangements was the investment incentive.

Investment incentives or state aids of the European Union had been discussed in the Treaty of Rome, heading "Rules on Competition", sub-heading "Assistance by Governments". In Article 107(1) of the Treaty of Rome it is stated "Save as otherwise provided in the Treaties, any aid granted by a Member State or through State resources in any form whatsoever which distorts or threatens to distort competition by favoring certain undertakings or the production of certain goods shall, in so far as it affects trade between Member States, be incompatible with the internal market".

In this sense "state aid" (MESS, 2012: 16) is defined as any aid granted by a member state which

- Has an effect on competition and trade between member states;

- Favoring certain companies (in other words, aid not covering the entire industry); 
- By providing advantage to the recipient;

- Through transfer of state resources.

Types of aid consistent with the internal market are discussed in Article 107(2) of the Treaty. Following types of aid are compatible with the internal market (Prime Ministry Secretariat General of the EU, 2011: 41):

a) aid having a social character, granted to individual consumers, provided that such aid is granted without discrimination related to the origin of the products concerned;

b) aid to make good the damage caused by natural disasters or exceptional occurrences;

c) Aid granted to the economy of certain areas of the Federal Republic of Germany affected by the division of Germany, in so far as such aid is required in order to compensate for the economic disadvantages caused by that division ${ }^{4}$. Five years after the entry into force of the Treaty of Lisbon, the Council, acting on a proposal from the Commission, may adopt a decision repealing this point.

In Article 107(3) aids that may be considered to be compatible with the internal market are given:

a) aid to promote the economic development of areas where the standard of living is abnormally low or where there is serious underemployment, and of the regions referred to in Article 349, in view of their structural, economic and social situation;

b) aid to promote the execution of an important project of common European interest or to remedy a serious disturbance in the economy of a Member State;

c) aid to facilitate the development of certain economic activities or of certain economic areas, where such aid does not adversely affect trading conditions to an extent contrary to the common interest;

d) aid to promote culture and heritage conservation where such aid does not affect trading conditions and competition in the Union to an extent that is contrary to the common interest;

e) Such other categories of aid as may be specified by decision of the Council on a proposal from the Commission.

Accordingly, in the sense of EU practices aspects of a state aid application may be summarized as follows (Özkarabüber, 2003; Özkumur, 2008: 4-6; Zemheri, 2009: 20; Soylu, 2008: 7): 
i) A transfer from state resources: A state aid measure requires waiver from a transfer made, or possibly will be made, from state budget, treasure or local resources, public banks or funds or other transfers that will absolutely take in place in the future.

ii) Economic advantage: It is a prerequisite for an aid to be considered a state aid that such economic advantage which an undertaking cannot obtain under its normal trading activities is given to that undertaking through a transfer from state resources.

iii) Selectivity: Feature of state aids which distinguish them from general measures is that state aids affect the balance between those selected and not selected on the basis of an undertaking, an industry, or a certain product.

iv) Effect on competition and trade: An aid beneficiary functioning in a market in which any two or more EU members' trade with each other results in an effect on the competition and trade between the member states; which is an aspect of state aids.

\subsection{Purposes of Incentives in the European Union}

Primary elements that shape incentive policies of the European Union are structural arrangement policies for enhancing international competitive power of Union states in terms of globalization, promoting private undertakings and investments within the Union, integration into world market and completion of internal market (Giray, 2008: 137-138; Özdaş, 2009: 42).

In this sense, prominent purposes of the incentive practices in the EU may be summarized as follows (Giray, 2008: 138-139):

- Taking into consideration different levels of development among member states, aids subject to certain conditions for promotion of the economic development of areas and states where the standard of living is abnormally low or where there is serious underemployment. For instance, aids undertaken to be granted between 2000 and 2006 to Bulgaria, Czech Republic, Estonia, Hungary, Latvia, Lithuania, Poland, Romania, Slovenia and Slovakia. With such aids it was aimed to eliminate differences between levels of development by supporting them before accession of the same.

- Getting use of incentive tools for remedy serious disturbances in the economy (such as unemployment, in particular crises arisen due to economic crises and regression and cyclical imbalances in industrialization) of a Member State; which is a requirement for common European interest.

- Increasing amount of investments within the Union.

- Providing incentives to industry within the Union to enable them to compete with other countries having strong and advanced technologies (such as the USA and Japan), and establishing national companies that are able to compete with such industries under equal conditions. 
- Taking into consideration contribution of small and medium scale establishments to the economy, acting in favor of supporting such establishments.

- Providing equal conditions for export industries within the EU in terms of costs.

\subsection{Control of State Aids in the $\mathrm{EU}$}

Aids demanded by EU states are delivered to the EU Commission in the form of a report together with justifications and targets of that demand. The Commission after a general examination discusses whether such aid will benefit in terms of the EU.

Figure 1: Procedure on Control of State Aids in the EU

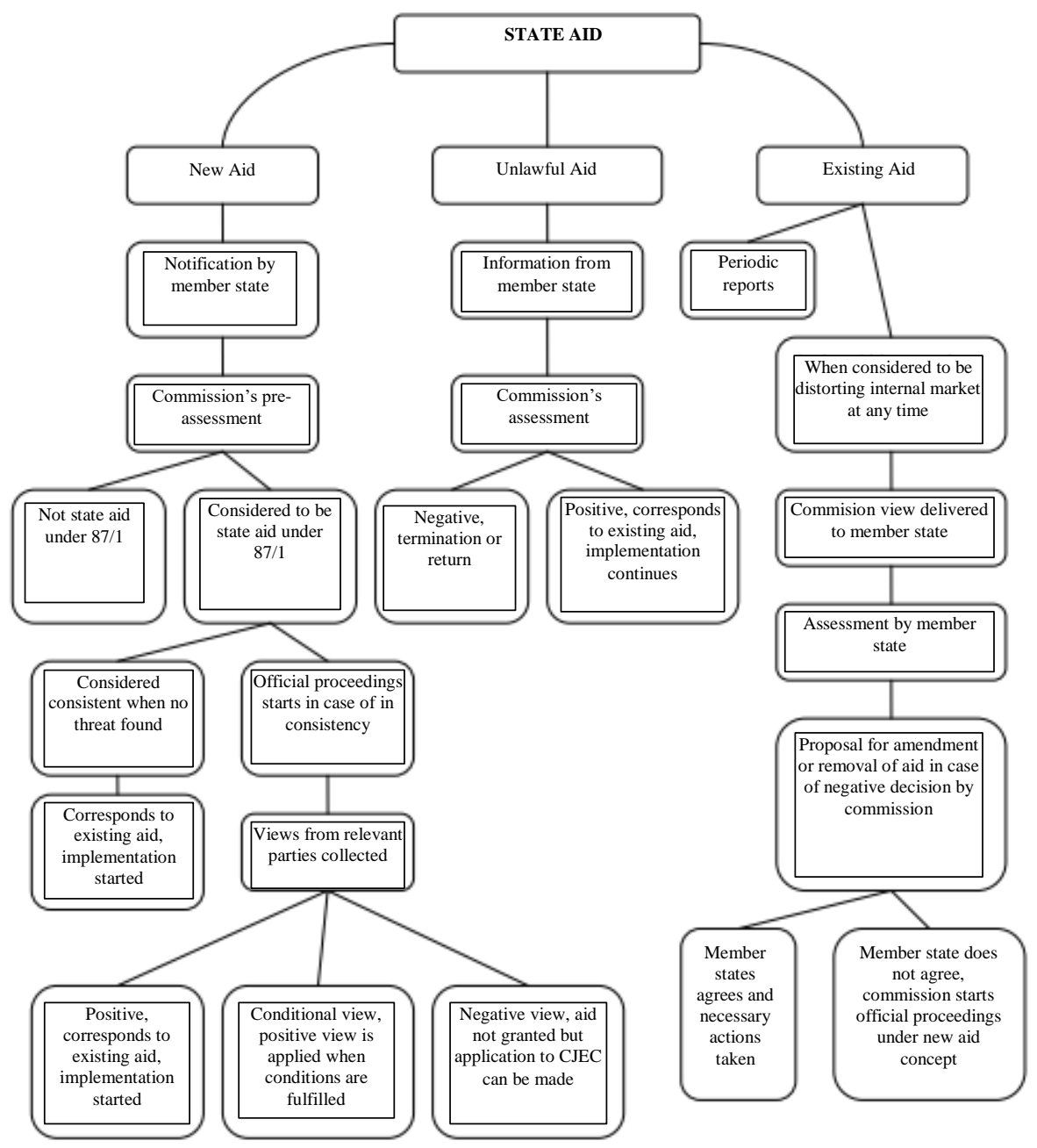

Source: Zemheri, 2009: 77. 
Regarding the country to which an aid will be granted the European Union acts in accordance with the above Figure 1. In this Figure state aids are divided into three categories: new aid, unlawful aid and existing aid. If a country completes relevant procedure given for each category of aid the European Union grants the aid. Another important point underlined in the Figure is that in case of a negative decision for an EU member state demanding a new aid the demanding member state has the right to apply to the Court of Justice of the European Communities $^{5}$. Decision given by the Court may affect the aid ${ }^{6}$.

\subsection{Types of Investment Incentives/Aids in the European Union}

Incentives applied in the EU are divided into four groups by the commission: Group A, Group B, Group C and Group D aids (Eker, 1995: 65-67; Giray, 2008: 139-140; Özdaş, 2009: 45; İnce, 2008: 85-87).

\section{Group A: Monetary Aid}

Such incentives are divided into two categories, namely $A_{1}$ and $A_{2}$. $A_{1}$ includes aids based on cash payments directly made from budget or funds to undertakings. Such monetary aids are aids granted for R\&D, energy saving, environmental programs, subsidy of expansion and modernization investments in SMEs, subsidy of on-the-job trainings, support to industries exposed to crisis (such as Greek crisis), interest subsidy, and building and rental subsidy. $A_{2}$ covers monetary aids provided indirectly and without cash payments such as tax exemption or abatement, accelerated amortization practices, tax deferral for institutions, deduction in social insurance premiums and local tax concession.

Group B: Contribution of State in equity capital through stock shares

A financial transfer made under normal circumstances to private and public establishments by a state to equity capital through stock shares. When stock shares of an undertaking whose shares are demanded under normal market conditions state may decide to assist that undertaking in overcoming such problem by contributing the undertaking's capital.

\section{Group C: Improved Credits}

Incentives of this group are applied in the form of lower interest rates and tax concession. For instance credits with lower interest rate of public or private resource,

5 The Court of Justice of the European Communities (ECJ) is the new name as of 1 December 2009.

6 The CJEC may make arrangement that can affect reulsts in accordance with Article 36 of the Association Council Decisions. 
accession credits of public or private resources, advances to be repaid in case of success, delayed tax positions-reserves and accelerated amortizations.

\section{Group D: State Guarantees}

It covers guarantees in the form of state guarantee against various risks that may be nominally expressed. Incentives of this group are the losses arisen due to guarantee programs excluding premium paid and amounts covered by the guarantee program. Purpose of such incentives is to enhance trading and export, support establishment of new companies and assist SME improvement.

Distribution of such types of incentives as of 2011 is as follows:

Table: 1

Distribution of Incentives in the EU (2011)

\begin{tabular}{|l|c|c|}
\hline Type of Aid/Incentive & Billion $\boldsymbol{\epsilon}$ & Share in Total Aids (\%) \\
\hline Grant/Donation & 30.4 & 57.33 \\
\hline Easier Credit & 1.6 & 2.97 \\
\hline State Guarantees & 1.6 & 2.96 \\
\hline Contribution to Capital & 0.2 & 0.42 \\
\hline Tax Exemption & 19.1 & 35.99 \\
\hline Others & 0.1 & 0.28 \\
\hline
\end{tabular}

Source: European Commission, 2012: 26.

As seen in Table 1 greatest share among total aids from the EU budget is of grants and donation, with a percentage of $57.33 \%$; followed by tax exemptions $(35.99 \%)$. These two kinds of aid form $85 \%$ of total aid.

\subsection{Content of State Aids in the EU}

State aids/incentives, under general approach of the EU, are classified as regional, sectoral and horizontal aids (Soylu, 2008: 9-26; P1nar and Sak, 2002: 326-327; Kutlu and Hacıköylü, 2007: 374-379; Yavan, 2011: 64).

Regional Aids: are aids granted in compliance with regional development policies of the EU in order to support development of less developed and underdeveloped regions and to reduce difference of development level between various regions of the EU.

Regional aids which correspond to 52.96 billion Euros compose $42 \%$ of aids granted by the European Union. Table 2 shows amounts and rational distribution of shares in regional aids received by EU member states. The most striking fact in this Table is that in particular Germany and France had received more aid in comparison to other countries. Germany receiving aid corresponding to 600 times of that received by Bulgaria and Estonia and France receiving aid corresponding to 500 time of the same had faced a significant financial disturbance during the economic crisis of 2008 and supported by the Union. In order to prevent a banking crisis in parallel to Turkish crisis of 2001 and since credits taken from German and French banks by other European countries were not duly paid in time the European Union had tolerated these two countries in terms of aids for monetary security of 
the Union. Similarly, Spain and England also take place among those who get greater shares in aids granted. Another important point is that Greece having a relatively smaller share in terms of both population and budget had received more aids in comparison to other member states. Leading motive was again the economic crisis.

\section{Table: 2}

\section{Distribution of Regional Aids in the EU (2011)}

\begin{tabular}{|c|c|c|c|c|}
\hline State & $\begin{array}{c}\text { Amount of Total Aid } \\
\text { (Billion } \epsilon)\end{array}$ & $\begin{array}{c}\text { Share in GDP of States } \\
(\%)\end{array}$ & $\begin{array}{c}\text { Change in Share of Aid in GDP of } \\
\text { States according to Preceding Year }(\%)\end{array}$ & $\begin{array}{c}\text { Share in GDP between } \\
2009 \text { and } 2011(\%)\end{array}$ \\
\hline Belgium & 1.24 & 0.34 & -0.21 & 0.46 \\
\hline Bulgaria & 0.02 & 0.05 & 0.01 & 0.07 \\
\hline Czech Republic & 1.17 & 0.76 & 0.12 & 0.64 \\
\hline Denmark & 0.83 & 0.35 & 0.03 & 0.51 \\
\hline Germany & 12.46 & 0.48 & -0.08 & 0.56 \\
\hline Estonia & 0.02 & 0.11 & 0.01 & 0.11 \\
\hline Ireland & 0.67 & 0.43 & -0.18 & 0.51 \\
\hline Greece & 2.17 & 1.01 & 0.24 & 0.86 \\
\hline Spain & 3.71 & 0.35 & -0.05 & 0.40 \\
\hline France & 10.48 & 0.52 & -0.12 & 0.60 \\
\hline Italy & 2.92 & 0.18 & -0.01 & 0.24 \\
\hline Southern Cyprus & 0.10 & 0.54 & 0.02 & 0.49 \\
\hline Latvia & 0.06 & 0.29 & -0.12 & 0.27 \\
\hline Lithuania & 0.12 & 0.40 & 0.10 & 0.37 \\
\hline Luxemburg & 0.08 & 0.19 & 0.00 & 0.22 \\
\hline Hungary & 0.86 & 0.86 & -0.89 & 1.33 \\
\hline Malta & 0.09 & 1.43 & 0.29 & 2.17 \\
\hline Holland & 1.78 & 0.30 & -0.02 & 0.30 \\
\hline Austria & 1.51 & 0.50 & -0.12 & 0.58 \\
\hline Poland & 2.13 & 0.58 & -0.17 & 0.73 \\
\hline Portugal & 1.75 & 1.02 & 0.16 & 1.64 \\
\hline Romania & 0.28 & 0.21 & 0.05 & 0.17 \\
\hline Slovenia & 0.33 & 0.91 & 0.13 & 0.89 \\
\hline Slovakia & 0.16 & 0.23 & -0.13 & 0.33 \\
\hline Finland & 1.06 & 0.56 & 0.12 & 0.49 \\
\hline Sweden & 2.79 & 0.72 & -0.03 & 0.76 \\
\hline England & 4.18 & 0.24 & -0.04 & 0.26 \\
\hline$E \boldsymbol{U}$ & 52.96 & 0.42 & -0.06 & 0.48 \\
\hline
\end{tabular}

Source: European Commission, 2012: 54.

Sectoral Aids: are state aids applied to enhance competitive power of certain sectors engaged in production and granted to sectors which lose power against Japan and the USA which are strong competitors of the EU, which cannot keep up with new competitive conditions and thus become in need of support and restructuring.

Table: 3

Distribution of Sectoral Aids among Total Aid in the EU (2011) (\%)

\begin{tabular}{|l|c|}
\hline Sector & Share in Total Aids in the EU \\
\hline Environment and Energy Saving & 23,40 \\
\hline Regional Aids & 26,39 \\
\hline Research, Development and Investment & 18,93 \\
\hline SMEs & 4,62 \\
\hline Trade & 1,46 \\
\hline Employment Aid & 2,74 \\
\hline Culture & 3,47 \\
\hline Export and Internationalization & 0,59 \\
\hline Social Aid to Individual Consumers & 6,43 \\
\hline Heritage Conservation & 0,12 \\
\hline
\end{tabular}

Source: European Commission, 2012: 56.

The EU which also developed a sector-based classification provides significant incentives and aids in order to eliminate imbalances at regional level; which is also proven 
by Table 3 showing that $26.39 \%$ of total aid has been assigned to eliminate imbalances between various regions.

Environmental and energy industry, becoming a serious sector due to global warming, is taken into consideration by the European Union; which is proven by the share assigned to it in total aids. Environmental and energy industry, receiving $23.40 \%$ of total aids, as a need of human life, has become a factor of high concern within the EU.

Research, development and investment expenses is one of the sector in which sustainable economies must invest; which is supported by the share (18.93\%) assigned in the member states. EU member states, with the R\&D and investment expenses made, targeted import substitution and started to produce in their own countries products and services which were previously imported.

Horizontal Aids: covers several types of incentives not intended for a certain sector or geographical region such as SME, R\&D, environment, employment, education, recovery and restructuring aids which are granted to provide companies with significant socioeconomic benefits in association with some economic policies of the EU.

Table: 4

Horizontal Aids in the EU

\begin{tabular}{|c|c|c|c|c|}
\hline \multirow[b]{2}{*}{ Type of Aid } & \multicolumn{2}{|c|}{ Region of Aid } & \multirow{2}{*}{$\begin{array}{c}\text { Other } \\
\text { Regions }\end{array}$} & \multirow[b]{2}{*}{ Category of Aid } \\
\hline & $\begin{array}{c}\text { Regions with level of development } \\
\text { under that of EU average }\end{array}$ & $\begin{array}{l}\text { Regions with level of development } \\
\text { under that of national average }\end{array}$ & & \\
\hline $\begin{array}{c}\text { Initial Investment } \\
\text { (Large-scale establishment) }\end{array}$ & 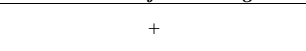 & (2) & - & Regional Aid \\
\hline Initial Investment (SME) & + & + & + & $\begin{array}{l}\text { Regional Aid \& } \\
\text { SME Aid }\end{array}$ \\
\hline $\begin{array}{l}\text { Creation of Employment in } \\
\text { Connection with Initial Aid } \\
\text { (Large-scale establishment) }\end{array}$ & + & + & - & Regional Aid \\
\hline $\begin{array}{l}\text { Creation of Employment in } \\
\text { connection with Initial Aid (SME) }\end{array}$ & + & + & + & $\begin{array}{l}\text { Regional Aid \& } \\
\text { SME Aid }\end{array}$ \\
\hline $\begin{array}{l}\text { Creation of Employment not in } \\
\text { connection with Initial Aid }\end{array}$ & + & + & + & Employment Aid \\
\hline Business Continuity & + & - & - & Employment Aid \\
\hline $\begin{array}{l}\text { Expenses for Environmental } \\
\text { Protection }\end{array}$ & + & + & + & $\begin{array}{l}\text { Environmental } \\
\text { Protection Aid }\end{array}$ \\
\hline$R \& D$ Expenses & + & + & + & $R \& D$ Aid \\
\hline Operating Aid & + & - & - & Regional Aid \\
\hline Transportation Aid & + & + & - & Regional Aid \\
\hline Soft Aids (SME) & + & + & + & SME Aid \\
\hline Vocational Aid & + & + & + & Vocational Aid \\
\hline
\end{tabular}

Source: Pinar and Sak, 2002: 327.

In this type of aid which hosts socioeconomic purposes rather than economic purposes, in addition to regional and sectoral aids, aids for human capital such as vocational aid and employment aid take place. 
Table: 5

Investment Incentive Tools employed in the European Union Member States

\begin{tabular}{|c|c|c|c|c|c|c|c|c|c|c|c|c|c|c|}
\hline \multirow[b]{2}{*}{ State } & \multicolumn{14}{|c|}{ Incentive Tools } \\
\hline & $\begin{array}{c}\text { Cash } \\
\text { (Grant/Premium) }\end{array}$ & Debt & $\begin{array}{c}\text { Tax } \\
\text { Deduction }\end{array}$ & $\begin{array}{c}\text { Reduced Social } \\
\text { Security }\end{array}$ & $R \& D$ & Environment/Energy & $\begin{array}{c}\text { Regional } \\
\text { Development }\end{array}$ & SMEs & \begin{tabular}{|l} 
Training of \\
Employees
\end{tabular} & Export & Technology & \begin{tabular}{|c|} 
Creation of \\
Job/Employment
\end{tabular} & \begin{tabular}{|c|}
$\begin{array}{c}\text { Investment } \\
\text { Assets }\end{array}$ \\
\end{tabular} & Sector-specific \\
\hline Austria & $*$ & * & & & * & * & * & * & & * & * & & & \\
\hline Belgium & * & & * & * & * & * & & * & * & & & * & * & \\
\hline Bulgaria & * & & * & * & & & * & & & & & * & & \\
\hline Southern Cyprus & * & & * & & * & * & & & * & & & & & \\
\hline Czech Republic & * & & * & & & & & & * & & & * & & * \\
\hline \multicolumn{15}{|l|}{ Denmark } \\
\hline Estonia & * & * & 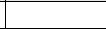 & & & & & & * & * & * & & * & \\
\hline Finland & * & * & * & & * & & * & & & * & & & & \\
\hline France & $*$ & & $*$ & & $*$ & & $*$ & & $*$ & & & $*$ & & \\
\hline Germany & $*$ & $*$ & $*$ & & $*$ & & * & & * & & & * & & \\
\hline Greece & * & & $*$ & & & & & & & & & $*$ & $*$ & * \\
\hline Hungary & * & & * & & & & * & & * & & & * & & \\
\hline Ireland & $*$ & & & & $*$ & & & & $*$ & & & $*$ & & \\
\hline Italy & $*$ & $*$ & $*$ & & & & $*$ & & & & $*$ & & & \\
\hline Latvia & * & * & & & 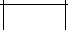 & & * & * & * & & & * & * & \\
\hline Lithuania & & * & * & & * & & * & * & & & & & & \\
\hline Luxemburg & * & & * & & * & * & * & * & & & & & & \\
\hline Malta & * & * & * & & * & & & * & * & & & * & * & \\
\hline \multicolumn{15}{|l|}{ Holland } \\
\hline Poland & * & & * & & & & * & & & & & & & * \\
\hline Portugal & & & $*$ & $*$ & $*$ & & & * & & & $*$ & & $*$ & \\
\hline Romania & $*$ & & $*$ & * & & * & $*$ & * & & * & & $*$ & & \\
\hline Slovakia & * & & $*$ & & & & & & & & & * & & \\
\hline Slovenia & * & & * & & * & & * & & * & & & * & & \\
\hline Spain & $*$ & $*$ & $*$ & * & $*$ & $*$ & & $*$ & $*$ & & & $*$ & & $*$ \\
\hline Sweden & $*$ & & & * & & & * & & & & & $*$ & & * \\
\hline England & * & & & & & & $*$ & & & & & * & & * \\
\hline Croatia & * & & * & & * & & * & & & & * & * & * & \\
\hline
\end{tabular}

Source: EU, 2010: 39-40, http://www.aik-invest.hr/en/, (10.04.2014).

Financial aid requires assessment of each project.

Investment assets include fixed assets (land, site, and equipment/machinery) and intangible assets. 
As shown in Table 4 all types of aid are granted to member states with a level of development under that of EU average. On the other hand, only employment aid aimed at business continuity is provided for regions with a level of development under that of national average $^{7}$.

\subsection{Investment Incentive Tools in the European Union States}

Today's economy, becoming more outward-oriented, results in rapid change and development in investments in the EU states. Elements which make investment attractive vary from country to country. Nonetheless, the common purpose of them is to attract relevant investments to countries. However, it is important for the Union to respect fundamental regulations with which the member states should comply. In this sense, each EU member state is trying to show that it is a country where important investment can be hosted by employing various investment incentive tools.

Table 5 shows incentive tools applied in 28 different EU member states. Variety of such tools underlines the importance attached by the EU member states to investment.

When incentive tools employed in the EU member states are examined following results can be derived:

- For incentives of Group A, B, C and D in the EU, almost every country provide monetary aid included in Group A and similarly many countries provide improved credits (easier credit/low-interest credit) included in Group C. on the other hand, contribution of government in equity capital through stock shares and state guarantees are less preferred incentive tools.

- For regional, sectoral and horizontal aids/incentives, support provided for regional level of development which is an important type of incentive in terms of balancing economic development of member states highlights regional incentives. Horizontal aids having a socioeconomic purposes rather than economic purposes also include incentives which are applied by the member states. Therefore, incentives to environment and energy industry in addition to those provided for economic profits prevent negative exclusion while other incentives such as those provided for training of employees, creation of employment are aimed at developing positive exclusion. Although there has not been a classification developed on sectoral basis there are also countries which grant sector-specific incentives. In other words, such countries provide both

7 National average means underdevelopment of a member state in comparison with the EU. In other words, the said member state, within its own country, low living standards and substantial unemployment (Pinar \& InceArıkan, 2003: 99). 
necessary opportunities to domestic and foreign entrepreneurs and sector-specific aids ${ }^{8}$.

When incentive policies and incentive tools adopted by the EU member states the most important finding is that aim of such aids and incentives is to provide positive acceleration for direct foreign investors in order to realize/support sustainable growth and economic development.

\section{Investment Incentives in some World Countries}

Today importance of permanent capital is continuously growing and many world countries give weight to investment incentives to reduce dependency on foreign countries and to enhance import substitution policy; which is also proven by the increase in incentive elements and positive indicators relating to direct foreign investment.

This section refers to investment incentives employed in the USA, China, Japan, Russia and South Korea which are considered to be developed countries.

\subsection{Investment Incentives in the USA}

On October $24^{\text {th }}, 1929$, which is also known as "Black Thursday", leading up to a change in the classical view, the New York Stock Exchange put an end to its stable and continuous rise; even some stock shares began to fall. Such fall was so persistent that it led to significant losses for the US economy.

The wording "supply creates its own demand" by Jean Baptiste Say became meaningless and free market economy which was called invisible hand fell in need of an intervention of a visible hand.

Adam Smith and his colleagues who deemed intervention of state to the economy baseless and adopted classical theory until 1929 in which the Great Depression took place could develop a solution for the crisis; which provided ground for birth of the Keynesian economy.

Although the USA is one of the countries which defend the idea that government should not intervene on the economy today it is a stubborn fact that state intervention is a requirement when global economy and globalization taken into account.

According to Seitzinger (2013) some quarters in the USA object intervention of government to the economy through investment incentive since it is a liberal policy which

For instance, several incentives such as grants, debt, tax reduction, etc. to an investor willing to make an investment in banking industry of country A are provided while the same investor can benefit also from sectorspecific incentives since he/she invests in the banking industry. 
the congress is not used to while others thinks that such an intervention would be welcome since it would be an important contribution in terms of employment ${ }^{9}$.

Main programs/industries supported by the US Federal government are as follows (Brickman, 2010):

- Agriculture

- Education/Research

- Energy/Technology

- Science/Technology

- Small-Scale Enterprises

- Real Estate

- Tax Policy Incentives

- Grant Resources and Investment Aid Programs.

When the above-given classification is examined it is found that US federal government places emphasis on the incentives for $R \& D$ investments. In addition to $R \& D$, the government also supported real estate industry in parallel to the economic crisis of 2008 and organized aid programs in order to inform investors.

Especially after the economic crisis of 2008 in addition to the US federal government other states also announced attractive incentive packages for investors. Such incentive packages are as follows (Baş-Uçar, 2013: 26-34):

- States most affected by the global crisis are Michigan, Indiana and Ohio which are considered the center of Midwestern region of United States. These states are offering empty facilities of companies which collapsed due to the crisis to domestic and foreign investors; even some facilities whose production is stopped are given free. When such facilities are made operational and significant employment opportunities are created local administrations and states can sometimes provide financial resources for renewal of such facilities.

- Free land is provided to investors in some cities and regions of several states such as Kansas, Nebraska, Iowa, Michigan and Maine. For instance, companies which will invest in industry in Musketon city of Michigan are granted with free land. As a precondition these companies should employ at least 25 people. A land of 5 decares is granted for an investment for 25 people while this value increases to 30 decares for 100 people. In Camsen a coastal city of Maine State a land of 3.5 decares is granted for free for each investment. For the first five years such 
companies are exempt from corporation tax and sales tax. Moreover, insurance premiums are also paid by Camden Municipality.

- Süha Çolakoğlu, CEO of USCO Capital Group, states that leading state in the Unites States in terms of grant of investment incentives is Texas. Çolakoğlu, emphasizing that Texas State allocates about 19 billion Dollars as incentive fund, declares that due to incentives granted within past 25 years, headquarters of the world's leading companies such as Dow Chemical, Texas Instruments and Samsung and other significant investments have been moved to Texas. Çolakoğlu, on incentives granted by North Dakota state, says "In North Dakota incentives are granted in order to support rural areas and to establish new residential areas. For areas with a population of less than 20000 people it is possible to get 50 percent of construction costs (up to 200 thousand Dollars) from the state as an incentive for new dwellings and structures".

- Substantial budget has been allocated from aid funds for new business areas, new establishments to be established under clean energy production and green environment programs. In addition, there are also considerable tax returns and exemptions for investments to be realized in pre-defined areas under zoning practices. In this respect, one of the key examples is the "Tax Exemption Programs" employed in Florida State. Undertakings realizing investments in predefined areas of Florida receive a tax return aid up to 3000 Dollars per employment at the end of relevant year. This amount increases to 6000 Dollars when such investment is in an industrial zone or other areas specified to be development areas. Moreover, in the same state if a company invests in several fields such as defense industry, space technologies and security it is exempt from corporation and income taxes for up to 20 years.

\section{Table: 6}

\section{Incentives and Credits granted by the US government by states 2000-2010 (million} Dollars)

\begin{tabular}{|c|c|c|c|c|c|c|c|c|}
\hline State & $\mathbf{2 0 0 0}$ & $\mathbf{2 0 0 4}$ & $\mathbf{2 0 0 5}$ & $\mathbf{2 0 0 6}$ & $\mathbf{2 0 0 7}$ & $\mathbf{2 0 0 8}$ & $\mathbf{2 0 0 9}$ & $\mathbf{2 0 1 0}$ \\
\hline Turkey & -80 & -298 & -225 & -191 & -296 & -43 & -28 & 46 \\
\hline Russia & 797 & 251 & -681 & -920 & -41 & 403 & 331 & 223 \\
\hline Korea & -132 & -110 & -43 & -43 & -40 & 182 & -68 & -67 \\
\hline Middle East & 4,345 & 8,413 & 16,705 & 10,220 & 10,195 & 10,801 & 9,608 & 9,028 \\
\hline Israel & 3,932 & 2,163 & 4,953 & 390 & 2,373 & 2,955 & 1,994 & 2,692 \\
\hline Iraq & $(Z) *$ & 5,040 & 10,857 & 9,157 & 7,039 & 6,228 & 5,269 & 2,942 \\
\hline
\end{tabular}

Source: US Census Bureau, The 2012 Statistical Abstract: 801-802.

*(Z) less than $\$ 500000$.

When incentives and credits granted by the US government to several countries between 2000 and 2010 it is found that Turkey had paid interest until 2010 without making any payment for credit capital received and in 2010 received 46 million Dollars without making any payment for interest.

One of the most important points that can be seen in Table 6 is the incentive and credit relationship between the USA and Middle East. Israeli lobby in the USA, recognized throughout the world, has achieved to get incentives and credits. In particular, share of Israel, 
receiving almost entire incentives before the US occupation of Iraq, in such incentives has been continuously decreasing.

Iraq, receiving less than 500000 Dollars in 2000, got $65 \%$ of aids made by the USA to Middles East (5040 million Dollars) in 2004 after overthrowing of Saddam in 2003. This amount is about 2.5 times that of granted to Israel. In 2010 the USA partially kept its hands off on Iraq; which was followed by the aids made for this region.

\subsection{Investment Incentives in China}

China, having a substantial share in the world's population, has a great potential labor force in connection with its population. Such a great labor force needs domestic investment and production. Chinese government, being aware of this fact, provides incentives for both domestic and foreign investors and encourages permanent investments. China in trying to control and shape domestic micro- and macro-economic indicators, in addition to permanent investments.

There is an important analogy between China and Turkey in terms of incentives. Such analogy is the importance attached to regional and sectoral incentives in both China and our country (UNCTAD, 2006: 76-77). In other words, there are incentives granted through regional classifications in our country; like some regions in China. In this case, it possible to conclude that there are also imbalances between regions in China and an effort to eliminate such imbalance through regional incentives.

Table 7 provides incentives granted by China to domestic and foreign investors. The most important point is the variety of establishments being supported.

Table: 7

\section{Types of Incentives in China}

\begin{tabular}{|c|c|c|c|}
\hline Type of Establishment & Type of Region & Pre-conditions & $\begin{array}{c}\text { Type of Incentive (Corporation } \\
\text { Tax) }\end{array}$ \\
\hline Foreign-capital enterprise & SEZs (Special Economic Zones) & & Tax rate applied\% 15 \\
\hline $\begin{array}{c}\text { Production-oriented Foreign- } \\
\text { capital enterprise }\end{array}$ & $\begin{array}{c}\text { ETDZs (Economic and } \\
\text { Technological Development Zone), } \\
\text { Shanghai, Pudong, Suzhou } \\
\text { Industrial Park }\end{array}$ & & Tax rate applied $\% 15$ \\
\hline $\begin{array}{c}\text { Production-oriented Foreign- } \\
\text { capital enterprise }\end{array}$ & $\begin{array}{l}\text { COEZs (Coastal Open Economic } \\
\text { Zone), former districts of cities in } \\
\text { which an SEZ or ETDZ had been } \\
\text { established }\end{array}$ & & Tax rate applied\% 24 \\
\hline $\begin{array}{c}\text { Production-oriented Foreign- } \\
\text { capital enterprise }\end{array}$ & BOCs (Border Open Cities) & Approval of local authority & $\begin{array}{l}\text { Tax rate applied } \% 24 \\
\text { (Information should be requested } \\
\text { from local authority for } \\
\text { additional incentives) }\end{array}$ \\
\hline $\begin{array}{c}\text { Production-oriented Foreign- } \\
\text { capital enterprise }\end{array}$ & $\begin{array}{c}\text { Former districts of cities in which a } \\
\text { COEZ, SEZ or ETDZ had been } \\
\text { established }\end{array}$ & $\begin{array}{c}\text {-high technology or } \\
\text {-Capital of more than } 30 \text { million US } \\
\text { Dollars } \\
\text {-relevance to port, wharf } \\
\text { construction or energy } \\
\text { And approval of local authority. }\end{array}$ & Tax rate applied $\% 15$ \\
\hline $\begin{array}{c}\text { Foreign banks, foreign-partnered } \\
\text { banks or other foreign financial } \\
\text { enterprises established with the } \\
\text { region }\end{array}$ & $\begin{array}{l}\text { SEZs, other regions in which } \\
\text { foreign-capital financial enterprises } \\
\text { may be established }\end{array}$ & $\begin{array}{l}\text {-at least } 10 \text { years of operational } \\
\text { period } \\
\text { - at least } 10 \text { million dollars of paid- } \\
\text { in capital from foreign investor } \\
\text {-approval of local tax authority }\end{array}$ & $\begin{array}{c}\text { - Tax exemption for } 1 \text { year from } \\
\text { first profit } \\
-50 \% \text { tax reduction for } \\
\text { subsequent } 2 \text { years }\end{array}$ \\
\hline
\end{tabular}




\begin{tabular}{|c|c|c|c|}
\hline $\begin{array}{l}\text { Foreign-capital enterprises } \\
\text { engaged in service industry }\end{array}$ & $\begin{array}{l}\text { SEZs, Xinglin and Taiwan } \\
\text { Investment Zones }\end{array}$ & $\begin{array}{c}\text { - at least } 10 \text { years of operational } \\
\text { period } \\
\text {-At least } 5 \text { million dollars of foreign } \\
\text { investment } \\
\text { - Approval of special zone tax } \\
\text { authority }\end{array}$ & $\begin{array}{l}\text { - Tax exemption for } 1 \text { year from } \\
\text { first profit } \\
-50 \% \text { tax reduction for } \\
\text { subsequent } 2 \text { years }\end{array}$ \\
\hline $\begin{array}{c}\text { High or new-tech Foreign-capital } \\
\text { enterprises }\end{array}$ & $\begin{array}{c}\text { HIDZs (High and New-Tech } \\
\text { Industrial Development Zones), } \\
\text { Beijing New Technology Industrial } \\
\text { Pilot Zone }\end{array}$ & $\begin{array}{c}\text { Approval evidencing that the } \\
\text { enterprise is a new or high-tech } \\
\text { enterprise }\end{array}$ & Tax rate applied $\% 15$ \\
\hline $\begin{array}{c}\text { High or new-tech Foreign-capital } \\
\text { enterprises }\end{array}$ & $H I D Z$ & $\begin{array}{c}\text { - at least } 10 \text { years of operational } \\
\text { period } \\
\text { - approval of local tax authority }\end{array}$ & $\begin{array}{c}\text { - Tax exemption for } 1 \text { year from } \\
\text { first profit } \\
-50 \% \text { tax reduction for } \\
\text { subsequent } 2 \text { years }\end{array}$ \\
\hline $\begin{array}{c}\text { High or new-tech Foreign-capital } \\
\text { enterprises }\end{array}$ & $\begin{array}{c}\text { High or new-tech Foreign-capital } \\
\text { enterprises }\end{array}$ & & $\begin{array}{c}\text { - Tax exemption for } 3 \text { years from } \\
\text { launching } \\
-50 \% \text { tax reduction for } \\
\text { subsequent } 3 \text { years }\end{array}$ \\
\hline $\begin{array}{l}\text { High-tech Foreign-capital } \\
\text { enterprises }\end{array}$ & $\begin{array}{c}\text { High or new-tech Foreign-capital } \\
\text { enterprises }\end{array}$ & $\begin{array}{c}\text { Export of at least } 40 \% \text { of total } \\
\text { production within any year after the } \\
\text { end of other tax advantages }\end{array}$ & Tax rate applied\% 10 \\
\hline Foreign-capital enterprises & Hainan SEZ, Shanghai Pudong & $\begin{array}{c}\text {-being engaged in infrastructure } \\
\text { projects such as airport, dock, wharf, } \\
\text { railway, road, coal pit, water } \\
\text { conservation, etc. } \\
\text {-at least } 15 \text { years of operational } \\
\text { period in the field of agricultural } \\
\text { development } \\
\text {-approval of local tax authority }\end{array}$ & $\begin{array}{c}\text { - Tax exemption for } 5 \text { years from } \\
\text { first profit } \\
\text { - 50\% tax reduction for } \\
\text { subsequent } 5 \text { years }\end{array}$ \\
\hline Foreign-capital enterprises & Shanghai Pudong & $\begin{array}{c}\text { being engaged in infrastructure } \\
\text { projects }\end{array}$ & Tax rate applied $\% 15$ \\
\hline $\begin{array}{c}\text { Production-oriented Foreign- } \\
\text { capital enterprises }\end{array}$ & Far and less developed regions & $\begin{array}{c}2 \text { years of tax exemption and } 3 \text { years } \\
\text { of tax reduction }\end{array}$ & $\begin{array}{l}\text { Tax reduction between } 15-30 \% \\
\text { for subsequent } 10 \text { years }\end{array}$ \\
\hline
\end{tabular}

Source: Beijing Embassy, Office of Trade Counselor,

$<$ http://www.musavirlikler.gov.tr/altdetay.cfm? AltAlanID $=874 \&$ dil $=$ TR\&ulke $=C H C>, 10.04 .2014$.

Incentives, varying depending on the type of undertaking are concentrated, in particular, on tax reduction. There are many tax reductions granted for various regions and industries while sometimes tax exemption is applied. Incentives granted are sometimes provided without any pre-condition while in some cases a certain amount of capital, a certain time period or approval of administrative authorities is required.

The most substantial corporation tax incentives granted to foreign-capital enterprises are summarized in Table 8.

\section{Table: 8}

\section{Corporation Tax Incentives in China ${ }^{10}$}

\begin{tabular}{|c|c|c|}
\hline Type of Establishment & Pre-conditions & Type of Incentive \\
\hline $\begin{array}{c}\text { Production-oriented foreign-capital } \\
\text { enterprise }\end{array}$ & $\begin{array}{c}\text { At least 10 years of production period (not applied } \\
\text { to enterprises engaged in production of petrol, } \\
\text { natural gas or rare metals) }\end{array}$ & $\begin{array}{c}\text { 1. } \\
\text { first profit and 50\% tax reduction for subsequent 3 } \\
\text { years }\end{array}$ \\
\hline $\begin{array}{c}\text { Foreign-capital enterprise engaged in } \\
\text { agricultural, forestry or livestock- } \\
\text { related activities }\end{array}$ & $\begin{array}{c}\text { At least 10 years of production period and being } \\
\text { in an area to be approved by official authorities }\end{array}$ & $\begin{array}{c}\text { Tax reduction between 15-30\% for 10 years after the } \\
\text { end of above-mentioned incentives }\end{array}$ \\
\hline $\begin{array}{c}\text { China-foreign company partnerships } \\
\text { engaged in port and wharf construction }\end{array}$ & At least 15 years of operational period & $\begin{array}{c}\text { Tax exemption for 5 years from the first profit and } \\
50 \% \text { tax reduction for subsequent } 5 \text { years }\end{array}$ \\
\hline
\end{tabular}

10 For further information on tax-related incentives applied in China see: Le, 2008. 


\begin{tabular}{|c|c|c|}
\hline $\begin{array}{c}\text { High-tech China-foreign company } \\
\text { partnerships }\end{array}$ & $\begin{array}{c}\text { A certificate of "High-tech statute" from Chinese } \\
\text { authorities }\end{array}$ & $\begin{array}{c}50 \% \text { tax reduction for 10 years after the end of any } \\
\text { tax incentive which provides at least 10\% advantage }\end{array}$ \\
\hline Exporting foreign capital enterprises & Exporting at least 70\% of total production & $\begin{array}{c}50 \% \text { reduction in the tax rate applied. Such } \\
\text { reduction may be made up to 10\% which is the } \\
\text { minimum tax base }\end{array}$ \\
\hline $\begin{array}{c}\text { Foreign-capital enterprises producing } \\
\text { raw materials or large amounts of } \\
\text { capital goods }\end{array}$ & $\begin{array}{c}\text { Accelerated depreciation (cannot benefit from tax } \\
\text { holidays granted to production-oriented foreign- } \\
\text { capital enterprises) }\end{array}$ \\
\hline
\end{tabular}

Source: Beijing Embassy, Office of Trade Counselor,

$<$ http://www.musavirlikler.gov.tr/altdetay.cfm? AltAlanID $=874 \&$ dil $=$ TR\&ulke $=C H C>$, 10.04.2014.

One of the points taken into consideration by capital owners for new investments is the rate of corporation tax which is taken according to corporate income. This rate has become more important due to the global competition. Almost every state has developed attractive environments for investments by reducing this tax rate.

Corporate tax also in China is made flexible under certain conditions. Chinese government, reducing such corporation tax rates, underlines that China is an important center for investments.

\subsection{Investment Incentive in Japan}

In japan, one of the leading economies of the world, investment has an important role in national economy. Japanese government, not taking into consideration investment as a tool for employment and economic growth, emphasizes that investments has many positive effects as mentioned below.

Figure: 2

\section{Effects of Investment Incentives in Japan}

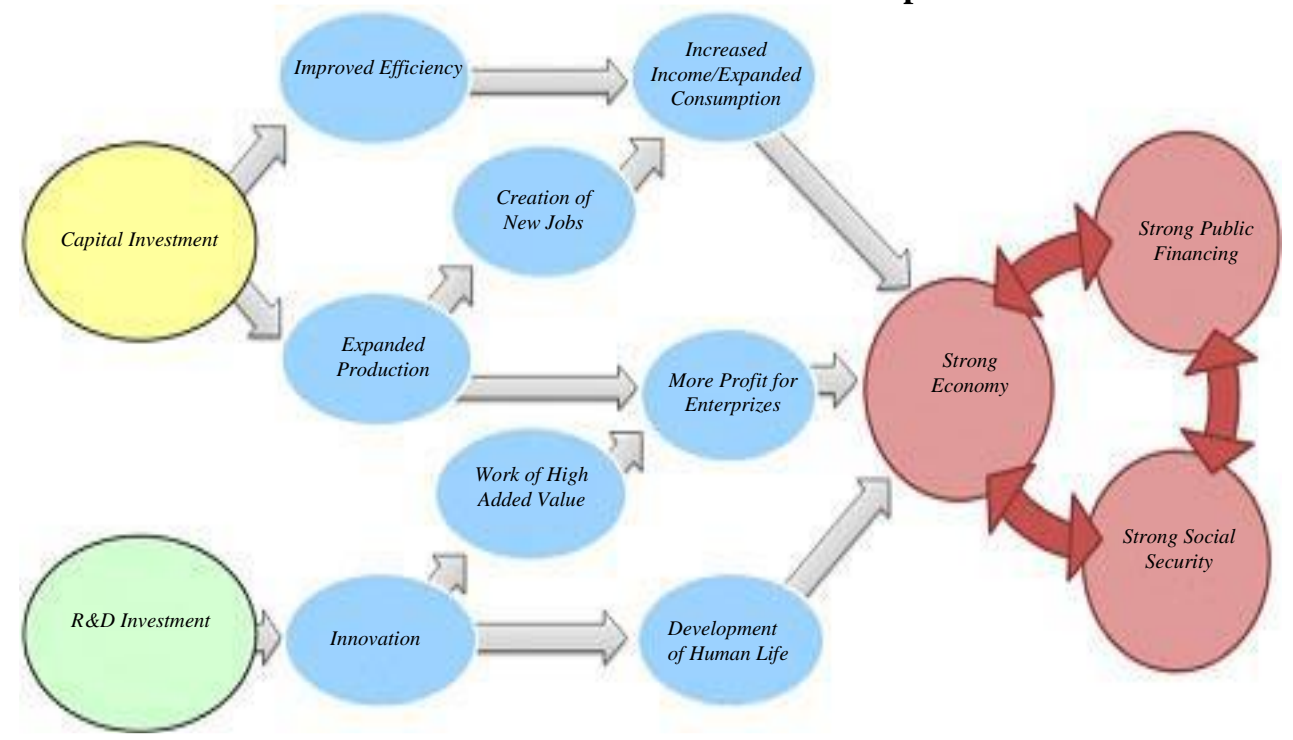

Source: METI, 2010: 4. 
Investment incentives, having the final aim to achieve strong economy, also lead to indirect positive effects such as increase in efficiency, expansion of production capacity and facilitation of innovations. In particular, incentive which will provide substantial support in terms of employment through expansion of production capacities, as in many other countries, is an alternative solution to prevention of unemployment in Japan. Figure 2 clearly shows that capital and R\&D investments to be made will result in a strong economy and subsequently in a strong public financing and social security.

Proposals developed in Japan to encourage investments are as follows (Sunesen vd., 2010: 110):

- System development for facilitating mergers and acquisitions;

- Corporate merger and acquisition activities in Japan (Increasing predictability of mergers and acquisitions).

- In time finalization of takeover rules.

- Support to studies for facilitation of cross-border mergers and acquisitions.

- Elimination of tiny problems in merger and acquisition activities carried out by foreign companies.

- Detailed studies on DYY regulations;

- Finalization of regulations when necessary as an exception to nondiscrimination principles between domestic and foreign investments on the grounds of DYY.

- Need to inform the remaining portion of world of open investment policy of Japan.

- Development of prioritized strategies by relevant industries;

- Development of the best medicine of the world in Japan.

- Selection of industries and formulations of action programs (in particular medical devices and pharmaceutical products.

- Reduction of operational costs and improvement of system's transparency;

- Reduction of corporation tax rate.

- Development of written reply procedures for taxes.

- Revision of judicial procedures.

- Promotion of private sector's dynamism for public services.

- Enabling foreign capital to provide regional revival;

- Increasing strategic attractiveness of foreign capital in terms of economic zones.

- Activities to attract foreign capital concentrated on former private sector personnel.

- Development of good living conditions for foreigners.

- Facilitation of business continuity of small and medium scale enterprises.

- Promotion of DDYs in Japan. 


\subsection{Investment Incentives in South Korea}

South Korea, fifth biggest cargo carrier, second biggest freight carrier and fifth highest high-speed train capacity of the world, shows that it is an ideal investment zone (PCNC, 2009: 6). In South Korea, which is a country suitable in terms of transportation costs, an important point for many investors, there are also other attempts to encourage investments. South Korean government provides such incentives in the form of tax-related supports under the Special Taxation Law. In addition, law called "Law on Foreign Investment Incentives" is another arrangement developed for investment (Shinwon Accounting Corporation, 2012: 17). Purposes of such tax-related incentives are to attract foreign investment movements, enhance performance of small and medium scale enterprises, to protect investors and support restructuring activities (PKF, 2013: 35). South Korean government, moreover, provides the following incentives (US Commercial Service, 2012: 74):

- Cash grants and R\&D centers for creation of high-tech businesses and expansion of workplaces.

- Arrangements on land and reduced prices for land investors.

- Grants for easy establishment of foreign facilities.

- Reduced costs for state or public goods.

- Optional financial aids for large scale infrastructure projects.

South Korea provides various aids such as long-term land allocation, tax exemption or exception, employment and logistics-related facilitations for, in particular, high-tech investments to be realized in free economic/trade zones. In addition, Korea EximBank has developed import aid funds in order to enhance import of certain strategic raw materials (Seoul Embassy, Office of Trade, <http://www.musavirlikler.gov.tr/altdetay.cfm?AltAlanID=901\&dil=TR\&ulke=GK >, 10.04.2014.

Five important corporate reforms on DYY are as follows (Kim, 2004: 2):

- Improvement of investment incentives,

- Liberalization of capital and foreign currency market,

- Reforms on corporate management systems,

- Correction of insufficient accounting practices,

- Elimination of obstructions against mergers and acquisitions.

Such reforms play an important role in terms of improvement of DYYs. In particular, the desire to improve existing investment incentives and attract foreign investors by eliminating obstructions against mergers and acquisitions proves the importance attached to DYYs by the government. Purpose of liberalization of capital and foreign currency markets is to facilitate improvement of DYYs. 


\subsection{Investment Incentives in Russia}

Russia, having large natural gas and oil resources, is one of the leading countries in the world in terms of raw material export. Russia in 2012 has become a member of the World Trade Organization (WTO) and agreed to apply WTO agreements and their provisions ${ }^{11}$.

Implementations to be put into force after Russian membership to the WTO can be summarized as follows (TEPAV, 2012: 9):

- Reduction of average customs tax rates,

- Elimination of non-tariff trade practices and bureaucratic obstacles against competition between Russian and foreign manufacturers/supplier and thus facilitation of entering into local market of foreign companies,

- Harmonization of Russian industrial state aid (subsidy) programs with WTO rules and reduction of the same; changes in subsidy programs which are provided under the precondition that products should be exported or used only in domestic market.

Under the undertakings for accession to the WTO, average consolidated customs taxes of Russia in 2011 which was about $10 \%$ was reduced to $7.8 \%$. in this context, consolidated customs tax rate for agricultural products reduced from $13.2 \%$ to $10.8 \%$; and from $9.5 \%$ to $7.3 \%$ for industrial products (Karabörklü, 2013: 7).

Advantages granted by the Russian government in order to attract investments are as follows (http://invest.gov.ru/en/why/reasons/):

- Dynamic economic growth,

- Being one of the largest consumer markets,

- Worldwide-known human capital ${ }^{12}$,

- Substantial natural resources,

- Geographical location,

- Technologically developed economy,

- Attractive taxation system,

- Comprehensive state aids,

- Stable social and political system.

11 Intellectual Property Agreement (TRIPS), General Agreement of Trade Service (GATS) and GATT Agreement 1994 are included in those agreements.

12 Worldwide-known human capital means the high number of well-known scientists and high literacy rate in Russia. (Russia, with 75 million of workers, literacy rate of $99,4 \%$ and 41 Nobel Prizes, takes the 7 th place in the world). 
Russian government, providing many advantages to attract investments, also draws attention by use of comprehensive state aids.

Russian government provides its incentives in technological development parks in terms of regional incentives and as investment fund, OAO Russian Enterprise Company and Development and Foreign Economic Relations Bank in terms of state-related aids. In addition, for special economic areas there are several incentives for industrial erection and taxation policy (http://invest.gov.ru/en/government_support/).

\section{Conclusion}

Economy which is a fragile concept has started to form itself according to incentives. Due to negative extrinsic effects of speculative indirect capital countries are now trying to find out how to attract direct investments. Depending on the substantial effect of global economic market and direct investments on state economies the European Union and many other world countries have realized the importance of investment incentives. Economic crises and fluctuations experienced have proven strength of investment incentives. Therefore, investment incentives have become a substantial policy tool in terms of having a word in the global economy and surviving economic fluctuations with minimum loss.

The European Union, like many other world countries, has given place to investment incentives in their own legislations. However, there are a couple of important points. First of them is that application of investment incentive policies without affecting competition within the Union. Another important point is that consideration of incentives/aids granted to member states by the Union whether any of them would produce benefit for the EU. In the study the table showing which EU member state employs what incentive tools to attract foreign investments should be taken into account. Thanks to the Table it is very easy to make a comparison between investment incentive tools employed by the member states. The place of both sectoral and regional incentives granted by the EU underlines the wide range of importance attached to investment incentives.

Investment promotion policies employed in the USA, China, Japan, South Korea and Russia, having a word in the global economy, in addition to the EU states are also examined in this study. Political aspect of incentives granted by the USA to other countries was found conspicuous. In particular, after US occupation of Iraq in 2003 Iraq among other Middles East countries had received incentives more than that received by Israel which is known to have an important economic and political lobby in the USA. Another important finding is that in addition to the federal government many states have also announced their own incentive packages.

In addition to the USA other countries such as China, Japan, South Korea and Russia which have a word in the global economy have also tried to attract foreign investments to their own countries through investment incentives. To do so, they have employed tools that were designed to reduce costs of investment. Such tools are mainly in the form of tax-related 
incentives and also cover applications aimed at minimizing costs for investors such as R\&D aid, allocation of investment place, interest aid and security premium employer share aid.

Incentives that will be able to find a place in todays and future economic planning will be basically sector-specific incentives that will enable stable economic growth and development.

\section{References}

Başbakanlık AB Genel Sekreterliği (2011), Avrupa Birliği Antlaşması ve Avrupa Birliği 'nin İşleyişi Hakkında Antlaşma, Ofset Fotomat, Ankara.

Baş-Uçar, R. (2013), “Amerika'da Yatırım Fırsatları”, Para Dergisi, (427), 26-34.

Bilici, N. (2007), Avrupa Birliği-Türkiye İlişkileri (Temel Bilgiler, İktisadi-Mali Konular), Seçkin Yayınc1lık, Ankara.

Brickman, A. (2010), Guide to Federal Incentives and Programs Available to Investors, Invest in America, U.S. Commercial Services.

Eker, A. (1995), Avrupa Birliği'nde ve Türkiye'de Teşvik Sistemleri ve Teşvik Politikaları, Doğuş Matbaacılık Ticaret Limited Şirketi, Ankara.

EU (2010), Foreign Direct Investment in the European Union, EU-Japan Centre for Industrial Cooperation.

European Commision (2012), "Facts and figures on State aid in the EU Member States", Commission Staff Working Paper, Autumn 2012 Update.

Giray, F. (2008), Vergi Teşvik Sistemi, Ezgi Kitabevi, Bursa.

İnce, M.G. (2008), "Yatırım Teşviklerin Yatırım Kararına Olan Etkisi ve Türkiye Uygulaması”, Yayınlanmamış Yüksek Lisans Tezi, İstanbul Üniversitesi Sosyal Bilimler Enstitüsü, İstanbul.

Jackson, J.K. (2012), Foreign Direct Investment in the United States: An Economic Analysis, Congressional Research Service.

Karabörklü, H. (2013), “Hoş geldin Rusya”, Gümrük Müşaviri Dergisi, (39).

Kim, W-S. (2004), “Korea's Institutional Reforms for Creating an FDI-friendly Environment”, APEC High-Level Conference on Structural Reform, <http://www.mofa.go.jp/policy/economy/apec/conference/present0409/session5-2.pdf>, 21.05.2013.

Kutlu, E. \& C. Hacıköylü, (2007), “Avrupa Birliği’ne Tam Üyelik Sürecinde Türkiye ve Avrupa Birliği Ülkelerinde Devlet Yardımları”, Anadolu Üniversitesi Sosyal Bilimler Dergisi, 7(1), 367-390.

Li, Q. (2008), “Tax Incentive Policies for Foreign-Invested Enterprises in China and their Influence on Foreign Investment”, Revenue Law Journal, 18(1), 8-13.

MESS (2012), "Rekabete İlişkin AB Müktesebat Rehberi”, <http://www.mess.org.tr/content/MESS\%20Rekabet\%20Rehberi\%20Nisan\%202012.pdf $>$, 13.05.2013.

METI (2010), "Inward Investment Promotion Program", <http://www.meti.go.jp/english/policy/economy/inward_investment/full_report.pdf>, 15.07.2013. 
Özdaş, Y. (2009), “Türkiye'de Uygulanan Yatırım Teşvikleri ve Diyarbakır Bölgesinde Bir Araştırma”, Yayınlanmamış Yüksek Lisans Tezi, Çukurova Üniversitesi Sosyal Bilimler Enstitüsü, Adana.

Özkarabüber, M.M. (2003), Avrupa Birliği ve Türkiye’de Devlet Yardımlarının Kontrolü, Rekabet Kurumu, Yayın No: 0135, Ankara.

Özkumur, N. (2008), “Avrupa Birliği’nde Devlet Yardımları ve Türkiye’nin Uyumu”, AB Uzmanlık Tezi, Tarım ve Köyişleri Bakanlığı Dış İlişkiler ve Avrupa Birliği Koordinasyon Daire Başkanlığı, Ankara.

Payne, D. \& F. Yu (2011), Foreign Direct Investment in the United States, U.S. Department of Commerce, Economics and Statistics Administration, Issue Brief: \#02-11.

PCNC (2009), KOREA Offering Opportunities: A year of regulatory reform by the Lee Myung-bak Administration, Presidential Council on National Competitinevess, Publication Number: 12-9780000-000009-14.

Pekin Büyükelçiliği Ticaret Müşavirliği (2014), <http://www.musavirlikler.gov.tr/altdetay.cfm?AltAlanID=901\&dil=TR\&ulke>, 10.04.2014.

Pınar, A. \& G. Sak (2002), “Avrupa Birliği Kapsamında Devlet Yardımları ve Türkiye’de Kamu Bankacılığı Deneyimi Üzerine Gözlemler”, 17.Türkiye Maliye Sempozyumu, Fethiye.

Pınar, A. \& S. İnce-Arıkan (2003), “Avrupa Birliği ve Türkiye'de Bölgesel Kalkınma Bağlamında Devlet Yardımları”, Ankara Avrupa Çalışmaları Dergisi, 3(1), 93-111.

PKF (2013), Doing Business in South Korea, <http://www.pkf.com/media/131978/doing\%20business\%20in\%20south\%20korea.pdf>, 11.02.2014.

Seitzinger, M.V. (2013), Foreign Investment in the United States: Major Federal Statutory Restrictions, Congressional Research Service.

Seul Büyükelçiliği Ticaret Müşavirliği (2014), <http://www.musavirlikler.gov.tr/altdetay.cfm?AltAlanID=901\&dil=TR\&ulke=GK>, 18.04.2014.

Shinwon Accounting Corporation (2012), Doing Business in South Korea, <http://www.cpaai.com/asiapacific/Doing_Business_in_Korea_-September2012.pdf>, 12.03.2013.

Soylu, H. (2008), "Devlet Yardımları ve Ekonomik Etkinlik: Avrupa Birliği ve Türkiye'deki Sistem”, Yayınlanmanış Yüksek Lisans Tezi, Ankara Üniversitesi, Sosyal Bilimler Enstitüsü, Ankara.

Sunesen R.E. \& J.F. Francois \& M.H. Thelle (2010), “Assessment of Barriers to Trade and Investment between the EU and Japan”, Final Report, Copenhagen Economics, Copenhagen.

TEPAV (2012), Rusya Federasyonu'nun Dünya Ticaret Örgütü'ne Katılımına İlişkin Değerlendirme, <www.deik.org.tr/Contents/FileAction/3780>, 15.05.2013.

UNCTAD (2000), “Tax Incentives and Foreign Direct Investment: A Global Survey”, United Nations Conference on Trade and Development, ASIT Advisory Studies, No: 16.

U.S. Census Bureau (2012), Statistical Abstract of the United States: 2012, <http://www.census.gov/compendia/statab/2012/tables/12s1297.pdf>, 11.03.2012. 
U.S. Commercial Service (2012), Doing Business in Korea: 2012, Country Commercial Guide for U.S. Companies, U.S. \& Foreign Commercial Service and U.S. Department of State.

Yavan, N. (2011), “Teşviklerin Sektörel ve Bölgesel Analizi: Türkiye Örneği”, Ekonomik ve Mali Araştırma Yarışması, Maliye Hesap Uzmanları Vakfı Yayınları, Ankara.

Zemheri, O. (2009), “AB'ye Üyelik Yolunda Devlet Yardımlarının Düzenlenmesi”, Uzmanlık Tezi, T.C. Başbakanlık Devlet Planlama Teşkilatı Müsteşarlığı, İktisadi Sektörler ve Koordinasyon Genel Müdürlügüu, Ankara. 